\title{
Perancangan Sistem Informasi Penginputan Data Kapal pada PT Barakomindo Shipping Cabang Sorong Berbasis Web
}

\author{
Hesty Ningsih Huwae ${ }^{1}$, Indri Anugrah Ramadhani ${ }^{2}$ Matahari $^{3}$ \\ Prodi Pendidikan Teknologi Informasi \\ Universitas Pendidikan Muhammadiyah Sorong \\ hestyningsihh@gmail.com ${ }^{1}$, indianugrah18@gmail.com ${ }^{2}$, mataharitarie@gmail.com ${ }^{3}$
}

\begin{abstract}
Abstrak: Penelitian ini bertujuan untuk menghasilkan sistem informasi penginputan data kapal pada di PT Barakomindo Shipping cabang Sorong berbasis web serta bagaimana cara penggunaannya. Metode Penelitian yang digunakan dalam pembuatan sistem informasi ini adalah jenis penelitian R\&D (Research and Development) dengan model perancangan Prototype. Metode pengujian sistem menggunakan black box testing, yang di uji oleh validator sistem dengan hasil pengujian sesuai tanpa terjadi eror pada sistem. Peneliti juga melakukan uji coba responden yang dilakukan pada staff PT Barakomindo Shipping. Berdasarkan hasil pengujian tersebut maka dapat dinyatakan bahwa Sistem Informasi Penginputan Data Kapal pada PT Barakomindo Shipping layak untuk digunakan.
\end{abstract}

Kata Kunci : data kapal; penginputan; sistem informasi; web.

\section{Pendahuluan}

Teknologi sudah mengarah kepada hal yang jauh lebih global seperti penggunaan web pada sebuah perusahaan. Website merupakan salah satu media informasi yang sangat efektif dalam menyajikan informasi, dengan kemajuan teknologi yang semakin meningkat maka sangat perlu dibuatkan sistem yang dapat membantu dalam pekerjaan dan juga dalam menyampaikan informasi. Adanya jaringan yang luas dan mudah diakses juga merupakan salah satu langkah untuk mendapatkan informasi dengan cepat, maka setiap instansi ingin mengubah sistem yang lama ke sistem yang baru agar tidak tertinggal dengan yang lain (Hayat, Prastica, Susanti, \& Isyamarwati, 2015).

Perkembangan teknologi informasi yang sangat pesat memberikan dampak positif bagi pelayanan di perusahaan khususnya yang bergerak dalam bidang industry, penjualan dan jasa. namun pemanfaatan teknologi informasi belum dimanfaatkan secara efektif pada PT Barakomindo Shipping cabang Sorong yang merupakan jasa pengurusan dokumen perkapalan yang datang dari penjuru kota di perairan RI maupun Manca Negara yang masuk di perairan sekitar kota Sorong Papua Barat. PT Barakomindo Shipping cabang Sorong dipimpin oleh Kepala Cabang dan dua orang Staff yang mempunyai jabatan sebagai bagian Keuangan dan bagian Operasional. Bagian keuangan kantor tidak ada kendala dalam penginputan data-data keuangan perusahaan yang bersifat privasi. Sedangkan, bagian operasional adalah bagian yang memiliki peranan dalam pengelolaan data perusahaan yang mencakup arsip dokumen kapal. Namun, tidak dipungkiri di dalam pengelolaan data yang dilakukan bagian operasional tetap dipantau oleh bagian keuangan dan juga pimpinan perusahaan.

Dokumen kapal yang terdiri dari kertas-kertas yang mudah sobek, hilang dan juga terbakar membuat pengarsipan dokumen tidak tepat. Saat mencari dan mendata arsip dokumen kembali pun memerlukan waktu. Masing-masing bagian memang mempunyai tugas yang berbeda, namun dalam penginputan data pada perusahaan masih manual. Dimana data hanya diambil dan diolah secara manual pada masing-masing staff di dalam perusahaan, sehingga sering terjadi ketidak sesuaian informasi yang didapat. 
Hal ini mengakibatkan diperlukan waktu yang lebih lama untuk melakukan proses pengecekan ulang. Perusahaan tersebut tentunya membutuhkan sistem informasi baik dalam pengelolaan data, informasi ataupun profil perusahaan. Dengan dibuatnya sistem penginputan data berbasis web memudahkan perusahaan dalam penginputan data perusahaan seperti data setiap kapal yang terdiri dari nama kapal, nama pemilik kapal, panjang keseluruhan kapal, dan data lainnya. Sistem akan memudahkan dalam pencarian dokumen setiap kali ada kapal yang harus diurus oleh perusahaan PT Barakomindo Shipping cabang Sorong. Adapaun studi literature yang relevan dengan penelitian ini adalah:

Hasil penelitian oleh Faizal Ari Prabowo, 2017, "Sistem Informasi Pengolahan Sertifikat Berbasis Web Di Divisi Training SEAMOLEC". Divisi Training SEAMOLEC dalam mengelola sertifikat masih menggunakan metode yang konvensional dimana masih menggunakan sistem mail merger dengan menggunnakan Microsoft Publisher dan Microsoft Excel. Merancang dan mengembangkan sistem informasi ini menggunakan metode waterfall dan untuk mengembangkan sistem menggunakan beberapa tahap yaitu analisis sistem yang berjalan, perancangan basis data, perancangan tampilan antarmuka dan pengujian program. Digunakan bahasa pemrograman Hypertext Preprocessor (PHP), perancangan basisdata menggunakan database MySQL, dan apache sebagai web servernya. Implementasi dari Sistem Informasi Pengolah Sertifikat Berbasis Web di divisi Training SEAMOLEC ini adalah dengan memanfaatkan teknologi internet yang berkembang saat Staff dapat melakukan proses cetak sertifikat di kantor maupun disaat melakukan tugas di luar wilayah kantor. Perbedaan antara jurnal dan peneliti terdapat di metode penelitian, jurnal menggunakan metode waterfall dan SDLC sedangkan peneliti menggunakan metode $R \& D$ dengan model penelitian sistem Prototype, tempat penelitiannya punberbeda pada jurnal dilakukan pada Di Divisi Training SEAMOLEC sedangkan peneliti pada PT. Barakomindo shipping.

Berdasarkan masalah tersebut peneliti berupaya untuk mengembangkan dan merancang sistem informasi penginputan data kapal agar dapat memudahkan perusahaan dalam penginputan dan juga memudahkan dalam pencarian data kapal.

\section{Metode Penelitian}

Dalam pembuatan sistem informasi jenis penelitian yang digunakan adalah metode pengembangan $\mathrm{R} \& \mathrm{D}$ (Research and Development). $\mathrm{R} \& \mathrm{D}$ (Research and Development) merupakan metode yang cocok digunakan dalam sebuah penelitian yang bertujuan untuk menghasilkan sebuah produk. R\&D (Research and Development) terdiri atas dua kata yaitu penelitian dan pengembangan. Sehingga model ini dapat diterapkan pada Perancangan Sistem Informasi Penginputan Data Kapal pada PT. Barakomindo Shipping cabang Sorong. Alur R\&D dapat dilihat pada Gambar 1.

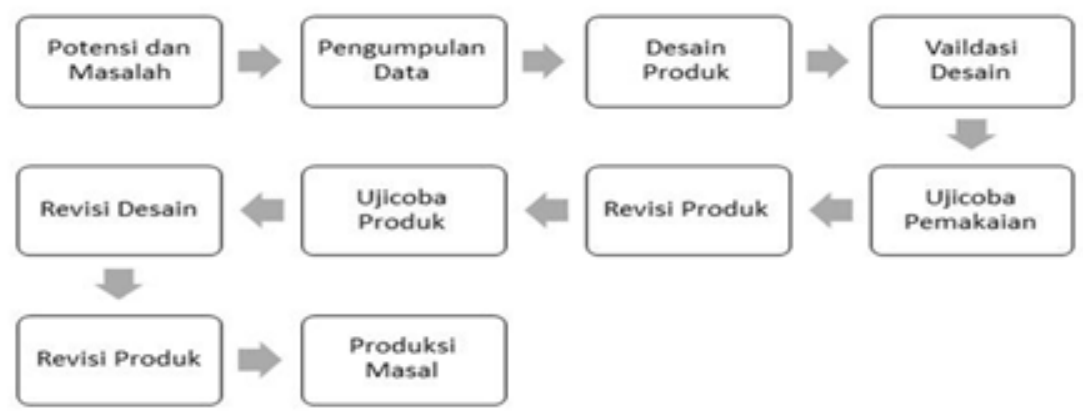

Gambar 1 Tahapan R\&D menurut Sugiyono, 2015 


\section{Hasil dan Pembahasan}

Hasil pengembangan sistem informasi penginputan data kapal berbasis web telah menghasilkan sistem informasi yang dapat berjalan dengan rancangan yang telah dibuat. Sistem informasi penginputan data berbasis web memiliki tiga user yang dapat masuk melewati satu pintu login dan di dalam masing-masing login user memiliki fungsinya sendiri. Karena terdapat tiga user maka setiap user memiliki sedikit perbedaan item dan fungsinya. Pada user Admin terdapat menu utama seperti profil admin, menu home, menu data pegawai, menu data kapal, menu sertifikat kapal, menu foto kapal, dan laporan (on-going, expired, dan deleted). Untuk user operasional terdapat menu utama seperti menu home, menu data pegawai, menu sertifikat kapal, menu foto kapal, dan laporan (on-going, expired, dan deleted). Sedangkan user kepala cabang terdapat menu utama seperti menu home, menu data pegawai, menu data kapal, menu sertifikat kapal, menu foto kapal, dan laporan (on-going, expired, dan deleted). Tampilan sistem dapat dilihat pada Gambar 2.



Gambar 1. Skor Tes Penguasaan Kosakata

Uji coba yang dilakukan untuk mengukur aplikasi yang telah dibuat menggunakan pengujian blackbox. Pengujian blackbox dilakukan dengan menilai seluruh fungsi dan navigasi dari sistem informasi penginputan data kapal pada PT Barakomindo Shipping Cabang Sorong. Pengujian blackbox dilakukan oleh validator ahli dalam bidangnya, dan dalam penelitian ini peneliti menggunakan salah satu dosen PTI (Pendidikan Teknologi Informasi) sebagai penguji blackbox. Komponen yang di ajukan adalah login admin, login operasional, dan login Kepala Cabang dari menu utama hingga menu keluar (logout). Rangkuman hasil pengujian Blackbox dapat dilihat pada Tabel 1. 
Tabel 1. Hasil uji coba Black Box

\begin{tabular}{|c|c|c|c|}
\hline No. & Rancangan Proses & Hasil Yang Diharapkan & Kriteria \\
\hline 1 & masuk menu home & $\begin{array}{l}\text { menampilkan logo dan profil } \\
\text { perusahaan. }\end{array}$ & sesuai \\
\hline 2 & $\begin{array}{l}\text { masuk menu data } \\
\text { pegawai }\end{array}$ & $\begin{array}{l}\text { menampilkan tampilan data pegawai } \\
\text { yang telah di input oleh user. }\end{array}$ & sesuai \\
\hline 3 & $\begin{array}{l}\text { button } \\
\text { Search/pencarian }\end{array}$ & $\begin{array}{l}\text { button Search berfungsi untuk pencarian } \\
\text { nama pegawai }\end{array}$ & sesuai \\
\hline 4 & $\begin{array}{l}\text { masuk menu } \\
\text { sertifikat kapal }\end{array}$ & $\begin{array}{l}\text { menampilkan menu sertifikat kapal yang } \\
\text { terdapat upload sertifikat kapal dan data } \\
\text { sertifikat kapal yang telah di input. }\end{array}$ & sesuai \\
\hline 5 & $\begin{array}{l}\text { isi form pada } \\
\text { upload sertifikat } \\
\text { kapal }\end{array}$ & $\begin{array}{l}\text { tampilan form pada upload sertifikat } \\
\text { kapal terdapat beberapa data kapal yang } \\
\text { harus diisi dan meng-upload sertifikat } \\
\text { dalam bentuk PDF }\end{array}$ & sesuai \\
\hline 6 & $\begin{array}{l}\text { klik button simpan } \\
\text { pada menu sertifikat } \\
\text { kapal }\end{array}$ & $\begin{array}{l}\text { klik button simpan untuk menyimpan } \\
\text { data kapal yang telah di ubah dan akan } \\
\text { menampilkan pemberitahuan bahwa data } \\
\text { kapal telah tersimpan. }\end{array}$ & sesuai \\
\hline 7 & $\begin{array}{l}\text { klik button hapus } \\
\text { pada menu } \\
\text { sertifikat kapal }\end{array}$ & $\begin{array}{l}\text { klik button hapus akan menampilkan } \\
\text { pemberitahuan bahwa ya atau tidak data } \\
\text { kapal akan di hapus }\end{array}$ & sesuai \\
\hline 8 & $\begin{array}{l}\text { klik tombol ya } \\
\text { pada menu hapus }\end{array}$ & klik tombol ya maka data akan terhapus & sesuai \\
\hline 9 & $\begin{array}{l}\text { klik tombol tidak } \\
\text { pada menu hapus }\end{array}$ & $\begin{array}{l}\text { klik tombol tidak maka data pegawai } \\
\text { batal dihapus }\end{array}$ & sesuai \\
\hline 11 & $\begin{array}{l}\text { button } \\
\text { Search/pencarian }\end{array}$ & $\begin{array}{l}\text { button Search berfungsi untuk pencarian } \\
\text { sesuai dengan nama kapal atau nama } \\
\text { sertifikat }\end{array}$ & sesuai \\
\hline 12 & $\begin{array}{l}\text { masuk menu foto } \\
\text { kapal }\end{array}$ & $\begin{array}{l}\text { menampilkan menu foto kapal yang } \\
\text { terdapat upload foto kapal dan foto kapal } \\
\text { yang telah di input. }\end{array}$ & sesuai \\
\hline 13 & $\begin{array}{l}\text { isi form pada } \\
\text { upload sertifikat } \\
\text { kapal }\end{array}$ & $\begin{array}{l}\text { tampilan form pada upload foto kapal } \\
\text { terdapat beberapa data kapal yang harus } \\
\text { diisi dan meng-upload foto kapal. }\end{array}$ & sesuai \\
\hline 14 & $\begin{array}{l}\text { klik button simpan } \\
\text { pada menu sertifikat } \\
\text { kapal }\end{array}$ & $\begin{array}{l}\text { klik button simpan untuk menyimpan } \\
\text { data kapal yang telah di ubah dan akan } \\
\text { menampilkan pemberitahuan bahwa data } \\
\text { kapal telah tersimpan. }\end{array}$ & sesuai \\
\hline 15 & $\begin{array}{l}\text { klik button hapus } \\
\text { foto pada menu } \\
\text { sertifikat kapal }\end{array}$ & $\begin{array}{l}\text { klik button hapus akan menampilkan } \\
\text { pemberitahuan bahwa ya atau tidak data } \\
\text { kapal akan di hapus }\end{array}$ & sesuai \\
\hline
\end{tabular}




\begin{tabular}{|c|c|c|c|}
\hline No. & Rancangan Proses & Hasil Yang Diharapkan & Kriteria \\
\hline 16 & $\begin{array}{l}\text { klik tombol ya pada } \\
\text { menu hapus foto }\end{array}$ & $\begin{array}{l}\text { klik tombol ya maka data akan } \\
\text { terhapus }\end{array}$ & sesuai \\
\hline 17 & $\begin{array}{l}\text { klik tombol tidak } \\
\text { pada menu hapus }\end{array}$ & $\begin{array}{l}\text { klik tombol tidak maka data } \\
\text { pegawai batal dihapus }\end{array}$ & sesuai \\
\hline 18 & $\begin{array}{l}\text { button } \\
\text { Search/pencarian }\end{array}$ & $\begin{array}{l}\text { button Search berfungsi untuk } \\
\text { pencarian nama kapal }\end{array}$ & sesuai \\
\hline 19 & masuk menu laporan & $\begin{array}{l}\text { masuk menu laporan akan } \\
\text { menampilkan } 3 \text { menu yaitu on- } \\
\text { going, expired, dan deleted. }\end{array}$ & sesuai \\
\hline 20 & $\begin{array}{l}\text { masuk menu } \\
\text { on- going }\end{array}$ & $\begin{array}{l}\text { masuk menu on-going akan } \\
\text { menampilkan data sertifikat yang } \\
\text { masih aktif. }\end{array}$ & sesuai \\
\hline 21 & masuk menu expired & $\begin{array}{l}\text { masuk menu expired akan } \\
\text { menampilkan data sertifikat yang } \\
\text { sudah expired atau sudah berakhir } \\
\text { masa berlakunya. }\end{array}$ & sesuai \\
\hline 22 & masuk menu deleted & $\begin{array}{l}\text { masuk menu deleted akan } \\
\text { menampilkan data sertifikat yang } \\
\text { telah di hapus oleh user. }\end{array}$ & sesuai \\
\hline 23 & klik logout & $\begin{array}{l}\text { klik logout pada menu home untuk } \\
\text { keluar dari user Operasional. }\end{array}$ & sesuai \\
\hline
\end{tabular}

Setelah hasil uji coba validator maka peneliti dapat melakukan uji responden di perusahaan tempat keguatan penelitian dilakukan. Di dalam responden terdapat 8 komponen dan 23 item dalam setiap responden yang di bagikan kepada setiap staff di dalam perusahaan PT Barakomindo shipping cabang sorong. Dari setiap item yang di berikan ada beberapa yang masih harus di lakukan perbaikan, seperti Ketepatan memilih warna teks, Ketepatan memilih jenis huruf, dan lainnya yang dapat di lihat dalam lampiran uji responden.

Setelah di lakukan uji responden dan dilakukan beberapa revisi kembali sistem penginputan data kapal, peneliti kembali melakukan uji responden kepada staff perusahaan. Uji responden selanjutnya mendapat hasil yang baik, dan layak digunakan. Uji responden yang ke 2 (dua) dapat dilihat dalam lampiran uji responden pada staff perusahaan.

\section{Kesimpulan}

Penelitian ini menghasilkan produk berupa Sistem Informasi Penginputan Data Kapal pada PT Barakomindo Shipping Sorong. Tahapan yang dilakukan untuk menghasilkan sebuah sistem absensi berbasis web antara lain, pengumpulan data, perencanaan, pengembangan bentuk awal produk, uji lapangan dan revisi produk, dan yang terakhir adalah implementasi Hasil dari uji coba produk mendapatkan hasil yang sesui tanpa ada error dilihat dari uji coba black box yang telah dilakukan oleh validator. Sehingga dapat disimpulkan bahwa sistem informasi penginputan data kapal layak untuk di gunakan. 


\section{Daftar Pustaka}

Abdulloh, R. (2016). Web Programming. Jakarta: PT Alex Media Komputindo.

Ahmad, C., Rini, E. S., \& Wiratama, I. W. A. (2016). Kota Pagar Alam Berbasis

Web. Ekspelora Informatika, 07(April), 36-49. Retrieved from https://eksplora.stikom-bali.ac.id/index.php/eksplora/article/view/66/52

Anwar, S., Efendi, Y., \& Dzuhri, A. M. (2016). Perancangan Sistem Informasi Data Trip Lintasan Perhari Cabang Merak Dan Laporan Ke Asdp Berbasis Web Pada Pt. Jemla Ferry. Studia Informatika: Jurnal Sistem Informasi Jl.

Apriliani, D., \& Somantri, O. (2015). Integrasi Fitur Back-End Untuk Pengembangan Sistem Informasi. Jurnal Teknologi Informasi Dan Komunikasi (JTIK) STMIK ProVisi Semarang, (2014), 21-27.

Ariyanto, J. T. (2016). No Title. Jurnal Pendidikan, 5(2), 107-116.

Ayu, F., \& Permatasari, N. (2018). Perancangan Sistem Informasi Pengolahan Data Praktek Kerja Lapangan (Pkl) Pada Devisi Humas Pt. Pegadaian. IntraTech, 2(2), 12-26.

Ayu Lestari, S., \& Armayah, M. (2016). Sistem Informasi Penjadwalan Kegiatan Belajar Mengajar Berbasis Web. 8(3), 6-10.

Destiningrum, M., \& Adrian, Q. J. (2017a). Sistem Informasi Penjadwalan Dokter Berbassis Web Dengan Menggunakan Framework Codeigniter. Tekn oinfo.

Destiningrum, M., \& Adrian, Q. J. (2017b). Sistem Informasi Penjadwalan Dokter Berbassis Web Dengan Menggunakan Framework Codeigniter (Studi Kasus: Rumah Sakit Yukum Medical Centre). Jurnal Teknoinfo. https://doi.org/10.33365/jti.v11i2.24

Ericko, F., Santoso, L. W., Setiawan, A., Studi, P., Informatika, T., Industri, F. T., ... Siwalankerto, J. (n.d.). Pembuatan Sistem Informasi Akuntansi Pada Toko NKL Surabaya dengan Menggunakan PHP dan MySQL.

Herliana, A., \& Rasyid, P. M. (2016). Sistem Informasi Monitoring Perkembangan Software pada tahap Development Berbasi Web. (1), 41-50.

Istiono, W., Hijrah, H., \& Sutarya, S. (2016). Pengembangan Sistem Aplikasi Penilaian dengan Pendekatan MVC dan Menggunakan Bahasa PHP dengan Framework Codeigniter dan Database MYSQL pada Pahoa College Indonesia. Jurnal TICOM, 5(1), 53-59. Retrieved from https://media.neliti.com/media/publications/93757-ID-pengembangan-sistemaplikasi-penilaian-d.pdf

Josi, A. (2017). DESA ( STUDI KASUS DESA SUGIHAN KECAMATAN RAMBANG ) STMIK-MUSIRAWAS LUBUKLINGGAU. 9(1).

Lestanti, S., \& Susana, A. D. (2016). Sistem Pengarsipan Dokumen Guru Dan Pegawai Menggunakan Metode Mixture Modelling Berbasis Web. Antivirus : Jurnal Ilmiah Teknik Informatika, 10(2), 69-77. https://doi.org/10.35457/antivirus.v10i2.164

M. Komarudin. (2016). Pengujian perangkat Lunak metode Black box berbasis partitions pada aplikasi sistem informasi di sekolah. Jurnal Mikrotik, o6(3), 02-16. https://doi.org/http://dx.doi.org/10.1016/j.brat.2012.09.004

Menggunakan, D., \& Dan, P. H. P. (2012). Salah satu bahasa pemrograman yang memungkinkan untuk dapat mendukung melihat jadwal secara online adalah 
PHP ( PHP Hypertext Preprocessor ), dimana PHP merupakan bahasa pemrograman berbasis web yang memiliki kemampuan untuk memproses data dinamis . . jQu. 4(November).

Novendri, M. S., Saputra, A., \& Firman, C. E. (2019). Aplikasi Inventaris Barang Pada Mts Nurul Islam Dumai Menggunakan Php Dan Mysql. Lentera Dumai, $10(2), 46-57$.

Novianto, D. (2016). Implementasi Sistem Informasi Pegawai (Simpeg) Berbasis Web Menggunakanframework Codeigniter Dan Bootstrap. Ilmiah Informatika Global, $\quad 7(1), \quad 10-16 . \quad$ Retrieved from http://ejournal.uigm.ac.id/index.php/IG/article/view/153

Pasaribu, J. S. (2017). Penerapan Framework YII pada Pembangunan Sistem PPDB SMP BPPI Baleendah Kabupaten Bandung. Jurnal Ilmiah Teknologi Terapan, 3(2), 154-163.

Prabowo, D. (2015). WEBSITE E-COMMERCE MENGGUNAKAN MODEL VIEW CONTROLLER ( MVC ) DENGAN FRAMEWORK CODEIGNITER Studi Kasus: Toko Miniatur. Data Manajemen Dan Teknologi Informasi (DASI), 16(1), 23.

Prasetyo, B., Pattiasina, T. J., \& Soetarmono, A. N. (2015). Perancangan dan Pembuatan Sistem Informasi Gudang (Studi Kasus: PT. PLN (Persero) Area Surabaya Barat). Teknika. https://doi.org/10.34148/teknika.v4i1.30

Prasetyo, F. S., \& Informasi, S. (2017). Rancang Bangun Sistem Informasi Pendataan Alumni Pada Stie Prabumulih Berbasis Website Dengan Menggunakan Bootstrap. Jurnal Informatika, 17(1), 1-10. https://doi.org/10.30873/ji.v17i1.972

PUTRA, D. W. T., \& PUTRA, J. J. (2018). Perancangan Sistem Informasi Pencarian Lowongan Pekerjaan. Jurnal Teknoif, 6(1), 48-54. https://doi.org/10.21063/jtif.2018.v6.1.48-54

Randi. (2015). Rancangan Sistem Informasi Keuangan Gereja Berbasis Web Di Jemaat GMIM Bukit Moria Malalayang. Teknik Elektro Dan Komputer, 4(7), $1-7$.

Sitohang, H. T. (2018). Sistem Informasi Pengagendaan Surat Berbasis Web Pada Pengadilan Tinggi Medan. Journal Of Informatic Pelita Nusantara Volume 3 No 1 Maret 2018 E-ISSN 2541-3724, 3(1), 6-9.

Sri Mulyani. (2016). Metode Analisis dan Perancangan. Bandung: Abdi Sistematika.

Tampubolon, P. (2018). Sistem Informasi Penjualan Barang Di Koperasi Pada Kantor Oditurat Militer I-02 Medan Berbasis Web. Jurnal Teknik Dan Informatika, 5(2), 86.

Widianti, U. D. (2012). Pembangunan Sistem Informasi Aset Di Pt.Industri Telekomunikasi Indonesia (Persero) Berbasis Web. Jurnal Ilmiah Komputer Dan Informatika (KOMPUTA), 1(2), 1-6. 